SAINS TANAH - Journal of Soil Science and Agroclimatology

Journal homepage: http://jurnal.uns.ac.id/tanah

\title{
Using Soil Quality Index Plus to assess soil conditions and limiting factors for dryland farming
}

\author{
Latief Mahir Rachman* \\ Department of Soil Science and Land Resource, Faculty of Agriculture, IPB University
}

\begin{tabular}{|c|c|}
\hline ARTICLE INFO & ABSTRACT \\
\hline Keywords: & Agriculture 3.0 and Agriculture 4.0 requires appropriate agricultural practices, including \\
\hline Crop productivity & soil data that are practical, accurate, and easy to understand. Using soil type maps and land \\
\hline Soil management & suitability class maps for soil information not only challenges users but also does not \\
\hline Soil quality assessment & provide soil quality information such as production potential and plant growth and \\
\hline Soil quality index & $\begin{array}{l}\text { production inhibitors. Other techniques that can provide more appropriate soil } \\
\text { information for agricultural purposes are thus needed. This research suggests the soil }\end{array}$ \\
\hline Article history & assessment system Soil Quality Index Plus, which provides accessible information \\
\hline Submitted: 2020-01-09 & regarding soil conditions and plant growth and production inhibitors in the context of \\
\hline Accepted: $2020-08-25$ & dryland farming. Field trials were conducted in 36 locations across five regencies in West \\
\hline Available online: $2020-12-30$ & $\begin{array}{l}\text { Java, Indonesia. Soil Quality Index Plus accurately assessed soil quality by using } 11 \text { key } \\
\text { parameters as a dataset: effective depth, texture class, bulk density, drainage, } \mathrm{pH} \text {, cation }\end{array}$ \\
\hline *Corresponding Autho & exchange capacity, total organic nitrogen, available phosphate, exchangeable potassium, \\
\hline $\begin{array}{l}\text { Email address: } \\
\text { latiefra@apps.ipb.ac.id }\end{array}$ & $\begin{array}{l}\text { aluminum saturation, and total carbon organic. The majority of the soils studied were } \\
\text { classified as medium soil quality, with low organic carbon being the most common limiting }\end{array}$ \\
\hline & $\begin{array}{l}\text { factor. Improved fertilizer management, especially the use of organic fertilizers, } \\
\text { phosphate- and nitrogen-based fertilizers, and agricultural lime should be implemented in } \\
\text { particular areas. }\end{array}$ \\
\hline
\end{tabular}

How to Cite: Rachman, L. M. (2020). Using Soil Quality Index Plus to assess soil conditions and limiting factors for dryland farming. Sains Tanah Journal of Soil Science and Agroclimatology, 17(2): 100-107 (doi: 10.20961/stjssa.v17i2.46889)

\section{Introduction}

To accelerate agricultural development in Indonesia to the point of self-sufficiency, particularly for staple food crops, Indonesia must combine Agriculture 3.0, which is characterized by precision technology and smart systems, with Agriculture 4.0, which is characterized by digitization. Soil is a fundamental and vital component of agriculture and particularly for Agriculture 3.0 and Agriculture 4.0, which both require practical, accurate, and easy-to-understand soil data in numerical and quantitative forms. The character of soil data should correspond to and support crop selection, agricultural management, and fertilizer recommendations.

Soil type maps and land suitability class maps are currently the main sources of soil information. However, they cannot fully support Agriculture 3.0 and Agriculture 4.0, which require more detailed information about soil quality, because they only provide information about soil type, soil formation processes, and the suitability of land for plant cultivation. Whereas information about soil that is needed for agricultural management to support more on a measurable and accurate Agriculture 3.0 and Agriculture 4.0 is information about 1) level of soil fertility, soil quality or soil productivity potential, 2) soil properties that inhibit plant growth and production, and 3) status and content of nutrient elements and other soil key elements to support accurate management and fertilizer recommendations. Measuring soil quality enables soil management to preserve the land, which is extremely important for the sustainability of human life and the global community (Kiani et al., 2017). Soil quality can also assess the sustainability of agriculture activities, as well as indicate how a particular soil can maintain crop and animal productivity, maintain or improve water and air quality, and protect human health (Sione, Wilson, Lado, \& González, 2017).

According to Doran and Parkin (1994), soil quality describes the capacity of the soil to function within the boundaries of an ecosystem to maintain biological productivity and environmental quality as well as to improve the health of plants and animals. Assessment is based on the 
physical, chemical, and biological properties of the soil; these provide information about various aspects of the soil as a system (Zuber, Behnke, Nafziger, \& Villamil, 2017). Soil quality also describes how soil fulfills its current role or purpose (Karlen, Andrews, Weinhold, \& Doran, 2003). Therefore, in the context of agricultural production, high soil quality is somewhat equivalent to high productivity and long-term resilience without significant soil or environmental degradation (Karlen et al., 2006; Kiani et al., 2017).

Evaluations of soil quality constitute a comprehensive index for soil management and sustainability assessments; however, given that soil is a complex medium, the quality of agricultural soil is divided into physical, chemical, and biological components (Imaz et al., 2010). The soil assessment system Soil Quality Index Plus (SQI-Plus) provides a score on a Soil Quality Index (SQI) as well as information about limiting factors that inhibit plant growth and production. The SQI is basically the weighted average index derived from selected soil key parameters, multiplied by a weighting coefficient. Using SQI-Plus, the SQI score is accompanied by letter(s) indicating the main parameter(s) determined to be limiting factor(s) for plant growth and plant production (Rachman, 2019a). The selected parameters should be easy to access and measure, unique but representative of soil conditions, and "sensitive enough" to changes in soil and environmental management. Compared with the effects of a soil management system over a certain period, a soil quality assessment can be classified as decreasing, unchanging, or increasing. Assessment can be descriptive and analytical. Descriptive assessment considers physical appearance, color, taste, and smell, while analytical assessment determines quantitative physical, chemical, and biological characteristics (Harris \& Bezdicek, 1994).

Arifin et al. (2016) also determined SQI using different methods to identify changes in soil quality resulting from different soil management approaches to dryland farming in Lombok, West Nusa Tenggara, Indonesia. Their research delivered recommendations that added fertilizer and bacterial inoculation could improve soil quality at research sites. Meanwhile, research about SQI by Martunis et.al. (2016) in Aceh, Indonesia concluded that each soil type would deliver a different SQI score. Both of these dryland farming studies expected that dryland farming would feature more inhibiting factors.

According to Rachman (2013), soil quality assessment is necessary to maintain and increase the productivity of the agricultural commodities needed for food self-sufficiency. Soil quality assessment involves considering the status or conditions of the soil to monitor and evaluate damage or recover soil quality in the case of poor soil management. Monitoring and evaluating soil quality can assist in the redesign of land management systems to achieve a sustainable soil and land use system.

This study uses SQI-Plus to obtain practical and understandable information about soil quality as well as information about factors that can inhibit plant growth and production. Specifically, the study considers soil quality in the context of dryland farming.

\section{Material and Methods}

\subsection{Study period and research site}

The research was conducted between March and December 2018. Soil samples observed and used for data were derived from 36 locations across five regencies in West Java, Indonesia, i.e. Sukabumi, Karawang, Subang, Garut, and Majalengka. Of those 36 locations, soil in 12 locations was planted with corn (Garut, Subang, and Sukabumi regencies), soil in 12 locations was planted with soybean (Garut, Subang, and Majalengka regencies), and soil in 12 locations was planted with peanut (Karawang, Subang, and Majalengka regencies). Figure 1 shows the distribution of the 36 observation locations on a map. Samples from five points were taken from each location (four corner points and one central point) to obtain one composite soil sample. Then, the sample was analyzed in the laboratory, repeating each analysis three times.

\subsection{Techniques and stages of soil quality assessment} using Soil Quality Index Plus

The first step in the process was selecting the parameters most vital for determining and managing plant growth and production; this led to 11 physical, chemical, and biological attributes being selected. This constituted the minimum dataset for the assessment using SQI-Plus. The 11 parameters were weighted differently for their different roles in plant growth and production; thus, each parameter was attributed to a weight coefficient (Table 1). There were 4 physical parameters analyzed in this research, which were: effective soil depth (S) measured using field observation method, texture $(T)$ measured using pipette method, bulk density $(B)$ measured using core sample/gravimetric method, and drainage (D) measured using field observation (Pansu \& Gautheyrou, 2006; Tan, 2005). There 6 chemical properties analyzed which were: $\mathrm{pH}$ using $\mathrm{pH}-\mathrm{H}_{2} \mathrm{O}$ method, Cation exchange capacity (CEC) using Extraction of $\mathrm{NH}_{4} \mathrm{OAc} 1 \mathrm{M} \mathrm{pH}$ 7.0 method, total organic nitrogen $\left(\mathrm{N}^{* *}\right)$ using Kjehdahl method, available phosphate $\left(\mathrm{P}^{* *}\right)$ using Bray I method, exchangeable potassium ( $\mathrm{Po}^{* *}$ ) using Extraction of $\mathrm{NH}_{4} \mathrm{OAc} 1$ $\mathrm{M} \mathrm{pH} \mathrm{7.0,} \mathrm{and} \mathrm{aluminum} \mathrm{saturation}\left(\mathrm{Al}^{* * *}\right)$ using Extraction of $\mathrm{KCl}$, filtering, and titration method (Sparks, Page, Helmke, \& Loeppert, 2020; Tan, 2005). The biological property analyzed was organic carbon $\left(\mathrm{Oc}^{* *}\right)$ measured using Walkley and Black method (Tan, 2005). The next step was scoring soil samples for each parameter from 0 to 5 (Table 2). This score was derived from the different categorizations for each key parameter, most of which have been used previously to assess soil properties by the Indonesian Center for Agricultural Land Resource Research and Development [Pusat Penelitian dan Pengembangan Sumberdaya Lahan Pertanian Indonesia], Bogor. The SQI score was the sum of the scores for every key parameter, which were obtained by multiplying the weighting coefficient by the score for each parameter.

\subsection{Soil quality index categorization}

After obtaining the SQI score, the next step was to classify the SQI scores into seven categories (Table 3) for interpretation and comparison. 


\subsection{Soil Quality Index Plus}

According to the SQI-Plus soil assessment system, a letter accompanying the SQI number (Figure 2 ) indicates whether the soil features parameters that might limit plant growth and production. Parameters with scores equal to or less than 2 $(\leq 2.00)$ are categorized as low and, thus, limiting factors.

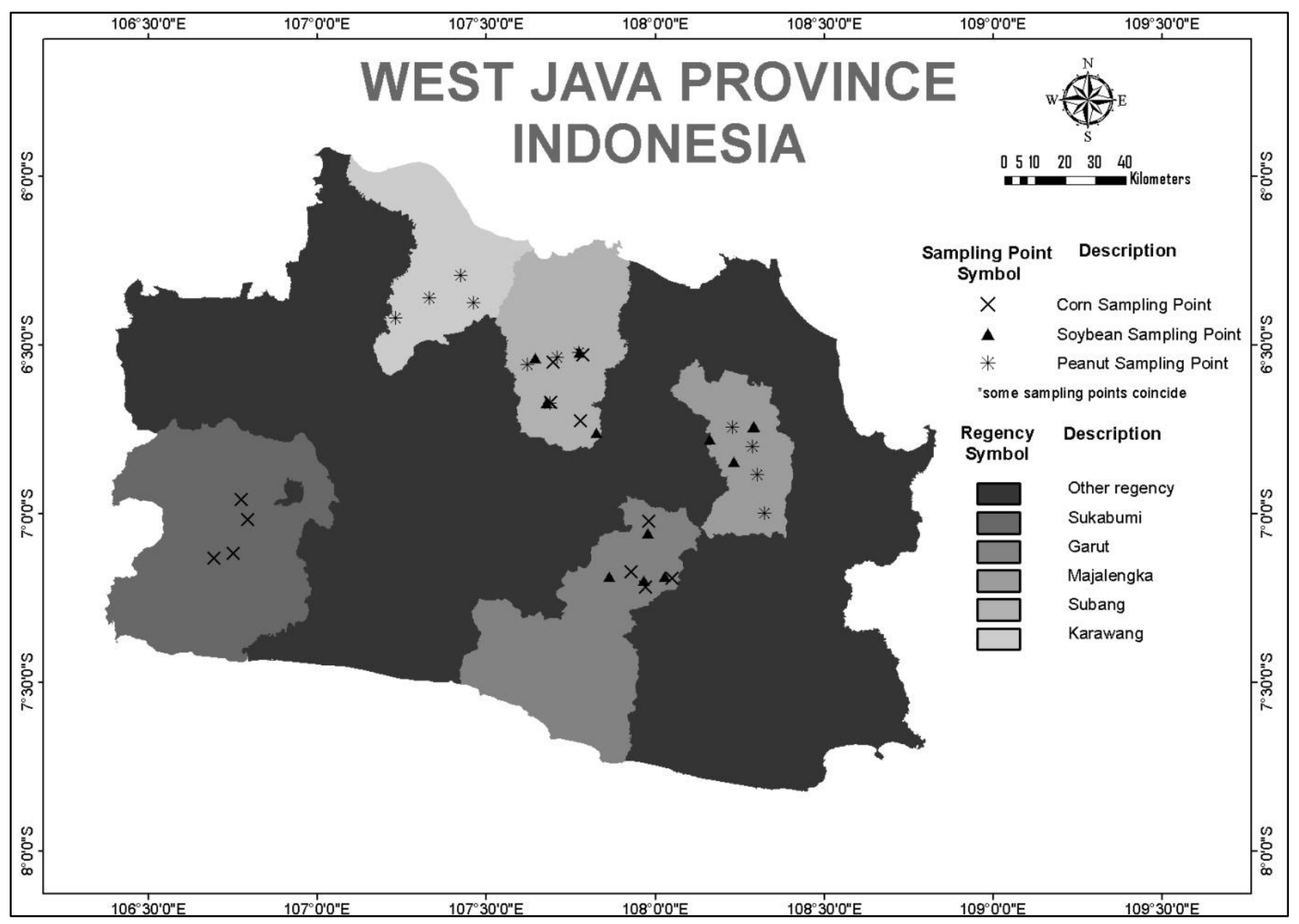

Figure 1. Map of research site

Table 1. Key parameters for assessment of Soil Quality Index (SQI)

\begin{tabular}{|c|c|c|c|c|}
\hline No & Symbol & Key Parameter & WC $^{*}$ & Method \\
\hline \multicolumn{5}{|c|}{ Physical Properties } \\
\hline 1 & $S$ & Effective soil depth & 0.09 & Field observation \\
\hline 2 & $\mathrm{~T}$ & Texture & 0.08 & Pipette \\
\hline 3 & B & Bulk density & 0.08 & Core sample (gravimetric) \\
\hline 4 & $\mathrm{D}$ & Drainage & 0.08 & Field observation \\
\hline \multicolumn{5}{|c|}{ Chemical Properties } \\
\hline 5 & $\mathrm{pH}$ & $\mathrm{pH}$ & 0.10 & $\mathrm{pH}-\mathrm{H}_{2} \mathrm{O}$ \\
\hline 6 & CEC & Cation exchange capacity & 0.07 & Extraction of $\mathrm{NH}_{4} \mathrm{OAc} 1 \mathrm{M} \mathrm{pH} 7.0$ \\
\hline 7 & $\mathrm{~N}^{* *}$ & Total organic nitrogen & 0.07 & Kjehdahl \\
\hline 8 & $\mathrm{P}^{* *}$ & Available phosphate & 0.07 & Bray I \\
\hline 9 & $\mathrm{Po}^{* *}$ & Exchangeable potassium & 0.07 & Extraction of $\mathrm{NH}_{4} \mathrm{OAc} 1 \mathrm{M} \mathrm{pH} 7.0$ \\
\hline 10 & $\mathrm{Al}^{* * *}$ & Aluminum saturation & 0.04 & Extraction of $\mathrm{KCl}$, filtering, and titration \\
\hline \multicolumn{5}{|c|}{ Biological Property } \\
\hline 11 & $\mathrm{Oc}^{* *}$ & Organic Carbon & 0.25 & Walkley and Black \\
\hline Total & & & 1.00 & \\
\hline
\end{tabular}


Table 2. Criteria used to score each parameter*

\begin{tabular}{|c|c|c|c|c|c|c|c|}
\hline \multirow{2}{*}{ Key parameters } & \multirow{2}{*}{ Unit } & \multicolumn{6}{|c|}{ Score } \\
\hline & & 0 & 1 & 2 & 3 & 4 & 5 \\
\hline \multicolumn{8}{|l|}{ Physical Properties } \\
\hline Effective soil depth & $\mathrm{cm}$ & $<10$ & $10-20$ & $20-40$ & $40-60$ & $60-80$ & $>80$ \\
\hline Texture & & $S$ & LS & SL & $\mathrm{HC}$ & C, SiC, Si & L,SiL, SCL, SiCL, CL, SC \\
\hline Bulk density & $\mathrm{g} \mathrm{cm}^{-3}$ & $>1.6$ & $1.4-16$ & $1.2-1.4$ & $1.0-1.2$ & $0.8-1.0$ & $<0.8$ \\
\hline Drainage & & Very bad & Bad & Slightly Bad & Fair & Slightly Good & Good \\
\hline \multicolumn{8}{|l|}{ Chemical Properties } \\
\hline $\mathrm{pH}$ & & $<4.0$ & $4.0-4.5$ & $\begin{array}{c}4.5-5.1 \& \\
8.5-9.0\end{array}$ & $\begin{array}{l}5.1-5.8 \& \\
8.0-8.5\end{array}$ & $\begin{array}{c}5.8-6.6 \& \\
7.5-8.0\end{array}$ & $6.6-7.5$ \\
\hline $\begin{array}{l}\text { Cation exchange } \\
\text { capacity }\end{array}$ & me $100 g^{-1}$ & $<2$ & $2-5$ & $5-16$ & $16-24$ & $24-40$ & $>40$ \\
\hline Total organic nitrogen & $\%$ & $<0.05$ & $0.05-0.11$ & $0.11-0.21$ & $0.21-0.51$ & $0.51-0.75$ & $>0.75$ \\
\hline Available phosphate & $\mathrm{ppm}$ & $<2$ & $2-4$ & $4-7$ & $7-10$ & $10-15$ & $>15$ \\
\hline $\begin{array}{l}\text { Exchangeable } \\
\text { potassium }\end{array}$ & me $100 \mathrm{~g}^{-1}$ & $<0.05$ & $0.05-0.1$ & $0.1-0.3$ & $0.3-0.6$ & $0.6-1$ & $>1$ \\
\hline Aluminum saturation & $\%$ & & $>40$ & $20-40$ & $10-20$ & $5-10$ & $0-5$ \\
\hline \multicolumn{8}{|l|}{ Biological Properties } \\
\hline Organic carbon & $\%$ & $<0.5$ & $0.5-1$ & $1-2$ & $2-3$ & $3-5$ & $>5$ \\
\hline
\end{tabular}

Remarks: C = clay; $\mathrm{HC}=$ heavy clay; $\mathrm{Si}$ = silt; $\mathrm{S}$ = sand; $\mathrm{L}=$ loam; $\mathrm{SiC}=$ silty clay; $\mathrm{SC}$ = sandy clay; $\mathrm{CL}$ = clay loam; $\mathrm{SiL}=$ silty loam; $\mathrm{SL}=$ sandy loam; $\mathrm{SiCL}$ = silty clay loam; $\mathrm{SCL}=$ sandy clay loam; $\mathrm{LS}=$ loamy sand; *Mostly derived from quantification of criteria which have been used to assess the soil properties by Indonesian Center for Agricultural Land Resource Research and Development [Pusat Penelitian dan Pengembangan Sumberdaya Lahan Pertanian Indonesia], Bogor.

Table 3. Soil Quality Index (SQI) categorization

\begin{tabular}{cccccccc}
\hline SQI Score & $x \leq 2.0$ & $2.0<x \leq 2.5$ & $2.5<x \leq 3.0$ & $3.0<x \leq 3.5$ & $3.5<x \leq 4.0$ & $4.0<x \leq 4.5$ & $x>4.5$ \\
\hline Category & Very bad & Bad & Slightly bad & Medium & Slightly good & Good & Very good \\
\hline
\end{tabular}

Remarks: $\mathrm{x}=\mathrm{SQI}$ score

\section{$\underset{\text { SQI Score }}{4.50}$}

Figure 2. Illustration of results as presented by Soil Quality Index Plus

\section{Results}

\subsection{Variation of soil physical, chemical, and biological} properties

The variability of soil quality was determined by variations of physical, chemical, and biological properties of soil samples. For physical properties, only 1 location (2.8\%) featured shallow soil $(30 \mathrm{~cm}$ ) (Table 4$)$, and only 3 locations $(8.3 \%)$ demonstrated high bulk density or dense soil structure $\left(>1.21 \mathrm{~g} \mathrm{~cm}^{-3}\right)$. Only 1 location (2.8\%) demonstrated coarse soil texture (loamy sand); other locations featured better soil texture. In terms of soil drainage, no location featured poor soil drainage and every location featured fair to good soil drainage.

In terms of chemical properties, only 1 location (2.8\%) demonstrated a good or neutral soil reaction $(\mathrm{pH}=6.3)$, while 9 locations (25.0\%) demonstrated $\mathrm{pH}$ below 5.1. Only 9 locations (25.0\%) demonstrated high cation exchange capacity (CEC) (>24 me $100 \mathrm{~g}^{-1}$ ); two demonstrated very high CEC (>40 me $\left.100 \mathrm{~g}^{1}\right)$ and 3 demonstrated low CEC $\left(<16\right.$ me $\left.100 \mathrm{~g}^{-1}\right)$. No location featured high levels of organic nitrogen $(>0.51 \%)$ and 18 locations (50.0\%) featured low levels of organic nitrogen $(<0.21 \%)$. While 11 locations (30.6\%) demonstrated high available phosphate (>10 ppm), 22 locations (61.1\%) demonstrated low available phosphate ( $<7 \mathrm{ppm})$. Eighteen locations (50.0\%) showed high exchangeable potassium $(>0.6$ me $100 \mathrm{~g}^{-1}$ ) and only 5 locations (13.9\%) showed low exchangeable potassium $\left(<0.3\right.$ me $\left.100 \mathrm{~g}^{-1}\right)$. Only 1 location $(2.8 \%)$ showed high aluminum saturation $(>20 \%)$. In terms of biological properties, only 3 locations (8.3\%) featured high levels of organic carbon content (3.0\%); 30 locations (83.3\%) featured low levels of organic carbon content $(<2.0 \%)$.

\subsection{Score and variability of SQI-Plus}

According to the 11 parameters used to assess soil quality with SQI-Plus, soil quality at the 36 locations studied did not vary substantially. Nonetheless, a higher SQI value indicated better soil quality. The highest SQI score (3.85) was found for location 8; this score is categorized as "slightly good". The lowest SQI score (2.75) was found at location 16; this score is categorized as "slightly bad"(Table 4). Of the 36 locations studied, 6 locations (16.7\%) featured "slightly good" soil quality, 23 locations (63.9\%) featured "medium" soil quality, and 7 locations (19.4\%) featured "slightly bad" soil quality. For the research locations, there was no soil quality that was categorized as "good", "very good", "very bad" or "extremely bad."

\subsection{Limiting factors derived from Soil Quality Index Plus}

Besides SQI scores, the letters attached SQI scores determined limiting factors for plant growth and production. The most common limiting factors were low carbon organic content (83.3\%), low available phosphate (61.1\%), low total organic nitrogen (50.0\%), and low soil pH (acidic soil, $25.0 \%$ ). 
Three locations demonstrated no limiting factors, all of which scored higher than 3.50 (Table 4). One location (Location 3) featured a hazardous level of aluminum saturation and one location could be considered to feature shallow soil.

\section{Discussion}

\subsection{The application and advantages of Soil Quality Index} Plus

Soil quality assessment was undertaken because of the insufficient soil information provided by widely used soil maps and land suitability maps. These maps only provide information regarding the soil type and land-suitability class, not directly representing soil conditions or quality. Additionally, they do not describe soil characteristics supporting or not supporting plant growth and production. Being qualitative in form, these tools are difficult to modify or change; thus, they are not useful for monitoring and evaluating soil conditions or measuring changes in soil conditions or quality as a result of agricultural management.

In contrast, SQI-Plus figures before and after soil or agricultural management interventions can be used to evaluate their usage, effectiveness, and productiveness. That is, SQI-Plus is more practical, sensitive, and easily understood in its function as a tool for evaluating and monitoring soil conditions (Rachman, 2019b). This notion is supported by other researchers who have suggested that soil quality can be used as a guide to the potential for soil productivity (Karlen et al., 2006; Kiani et al., 2017). Furthermore, soil quality assessment is a form of soil assessment that summarizes soil according to different concepts (Bünemann et al., 2018).

For this research, SQI assessment was chosen for its ability to deliver quantitative soil information; that is, the numbers collected for key parameters represented characteristics essential to determining plant growth and production. This technique is a more practical, simple, and accessible means of describing soil conditions, soil quality, and soil productivity. Tesfahunegn (2014) also assessed soil quality to evaluate soil degradation in northern Ethiopia. Soil quality evaluation can constitute a comprehensive index for assessing soil management and land sustainability; the soil being a very complex medium, the quality of agricultural soil can be observed according to physical, chemical, and biological components (Imaz et al., 2010). An SQI can identify productivity problems, make realistic estimates of food production, evaluates land and soil management, and agricultural systems. It also can be used to evaluate the benefits of public investment in agricultural policy programs.

\subsection{Disadvantages of Soil Quality Index Plus}

An SQI is a weighted average number; thus, it is possible that even though an SQI score is high due to high scores on various parameters, productivity potential might not be high due to one or several low-scoring parameters $(\leq 2.00)$ preventing optimal plant growth and production. To overcome this weakness, SQI-Plus was developed to include parameters inhibiting plant growth and production (Figure 2). More letters attached to the SQI score indicates there are more limiting factors in the soil. For example, an SQI-Plus score for a soil sample is 3.03 pH.N.P.Po.Oc indicates that the soil is of "medium" soil quality with limiting factors being low levels of organic nitrogen, available phosphate, exchangeable potassium, and organic carbon, as well as an acidic soil reaction; these factors limit the availability of essential nutrients for plants.

Table 4. Results of soil quality assessment using Soil Quality Index Plus

\begin{tabular}{|c|c|c|c|c|}
\hline Location & $\begin{array}{l}\text { SQI } \\
\text { Score }\end{array}$ & $\begin{array}{l}\text { Limiting } \\
\text { Factors }\end{array}$ & SQI Plus & Category \\
\hline \multicolumn{5}{|l|}{ Corn } \\
\hline 1 & 3.59 & $S$ & $3.59 \mathrm{~S}$ & Slightly good \\
\hline 2 & 3.05 & pH.P.Po.Oc & 3.05 pH.P.Po.Oc & Medium \\
\hline 3 & 3.02 & pH.Al.Oc & 3.02 pH.Al.Oc & Medium \\
\hline 4 & 3.14 & pH.P.Oc & 3.14 pH.P.Oc & Medium \\
\hline 5 & 2.95 & N.P.Oc & 2.95 N.P.Oc & Slightly bad \\
\hline 6 & 3.46 & Oc & $3.46 \mathrm{Oc}$ & Medium \\
\hline 7 & 3.64 & - & 3.64 & Slightly good \\
\hline 8 & 3.85 & - & 3.85 & Slightly good \\
\hline 9 & 3.09 & pH.N.P.Oc & 3.09 pH.N.P.Oc & Medium \\
\hline 10 & 3.32 & N.Oc & 3.32 N.Oc & Medium \\
\hline 11 & 3.03 & pH.N.P.Po.Oc & 3.03 pH.N.P.Po.Oc & Medium \\
\hline 12 & 3.27 & N.P.Oc & 3.27 & Medium \\
\hline \multicolumn{5}{|l|}{ Soybean } \\
\hline 13 & 3.06 & N.P.Oc & 3.06 N.P.Oc & Medium \\
\hline 14 & 3.19 & N.P.Oc & 3.19 N.P.Oc & Medium \\
\hline 15 & 3.13 & N.P.Oc & 3.13 N.P.Oc & Medium \\
\hline 16 & 2.75 & pH.N.P.Oc & 2.75 pH.N.P.Oc & Slightly bad \\
\hline 17 & 2.98 & Cec.P.Oc & 2.98 Cec.P.Oc & Slightly bad \\
\hline 18 & 3.24 & N.Oc & 3.24 N.Oc & Medium \\
\hline 19 & 3.21 & P.Po & 3.21 P.Po & Medium \\
\hline 20 & 3.50 & $\mathrm{Cec}$ & $3.50 \mathrm{Cec}$ & Medium \\
\hline 21 & 2.95 & T.pH.Oc & 2.95 T.pH.Oc & Slightly bad \\
\hline 22 & 3.41 & P.Oc & 3.41 P.Oc & Medium \\
\hline 23 & 3.62 & N.Oc & 3.62 N.Oc & Slightly good \\
\hline 24 & 3.54 & N.Oc & 3.54 N.Oc & Slightly good \\
\hline \multicolumn{5}{|l|}{ Peanut } \\
\hline 25 & 3.04 & B.N.P.Oc & 3.04 B.N.P.Oc & Medium \\
\hline 26 & 3.26 & N.P.Oc & 3.26 N.P.Oc & Medium \\
\hline 27 & 3.27 & N.Oc & 3.27 N.Oc & Medium \\
\hline 28 & 3.30 & N.P.Oc & 3.30 N.P.Oc & Medium \\
\hline 29 & 3.34 & P.Oc & 3.34 P.Oc & Medium \\
\hline 30 & 3.19 & N.P.Oc & 3.19 N.P.Oc & Medium \\
\hline 31 & 2.78 & pH.Cec.P.Oc & 2.78 pH.Cec.P.Oc & Slightly bad \\
\hline 32 & 3.75 & - & 3.75 & Slightly good \\
\hline 33 & 3.09 & pH.P.Oc & 3.09 pH.P.Oc & Medium \\
\hline 34 & 3.25 & N.Oc & 3.25 N.Oc & Medium \\
\hline 35 & 2.84 & B.P.Po.Oc & 2.84 B.P.Po.Oc & Slightly bad \\
\hline 36 & 2.88 & B.P.Po.Oc & 2.88 B.P.Po.Oc & Slightly bad \\
\hline
\end{tabular}

Remark: $\mathrm{S}$ = effective depth; $\mathrm{B}=$ bulk density; $\mathrm{T}$ = texture; $\mathrm{pH}=$ soil $\mathrm{pH}$; $\mathrm{Cec}=$ cation exchange capacity; $\mathrm{N}=$ total organic nitrogen; $\mathrm{P}=$ available phosphate; $\mathrm{Po}=$ exchangeable potassium; $\mathrm{Al}=$ aluminum saturation; Oc = organic carbon 
Table 5. Limiting factors observed on research sites

\begin{tabular}{lcc}
\hline Limiting Factors & $\begin{array}{c}\text { Location } \\
\text { Number }\end{array}$ & $\begin{array}{c}\text { Percentage } \\
\text { (\%) }\end{array}$ \\
\hline Organic carbon (Oc) & 30 & 83.3 \\
Available phosphate(P) & 22 & 61.1 \\
Total organic nitrogen (N) & 18 & 50.0 \\
Soil reaction (pH) & 9 & 25.0 \\
Exchangeable potassium (Po) & 5 & 13.89 \\
Bulk density (B) & 3 & 8.33 \\
Effective depth (S) & 1 & 2.78 \\
Texture (T) & 1 & 2.78 \\
\hline
\end{tabular}

\subsection{Implications of Soil Quality Index Plus scores for} samples

Using SQI, this study's results provide early indications that the soil at this study's locations is in a critical condition demanding serious attention. Table 4 shows that most of the soil studied (63.9\%) was considered "medium" quality, 19.4\% was of "slightly bad" quality, and only $16.7 \%$ was of "slightly high" quality. No soil samples were classified as high or very high quality.

The majority of the soils studied (83.3\%) featured low or very low organic carbon content $(<2 \%)$, indicating that organic material was rarely applied in the agricultural systems of the areas studied. Twenty-two locations (61.1\%) featured low available phosphate content $(<7 \mathrm{ppm}), 18$ locations $(50 \%)$ demonstrated low total organic nitrogen $(<0.21 \%)$, and 9 locations produced soil reactions that are classified as very acidic $(\mathrm{pH}<5.1)$. This indicates that many of the locations studied need to improve soil management by increasing fertilization with phosphate and nitrogen and applying agricultural lime, especially in the locations experiencing a deficiency of these elements (Table 5).

In similar studies, Arifin et al. (2016) observed low levels of organic carbon and nitrogen on dryland farms in Lombok, West Nusa Tenggara, and Martunis et al. (2016) reported that some dryland farming areas in Aceh Besar featured low levels of organic carbon, nitrogen, and available phosphate.

Lower SQI scores were observed to feature more associated letters, that is, more limiting factors. Most soil samples from the study location (91.7\%) featured one or more factor limiting plant growth and production. Only 3 locations (8.3\%) showed no limiting factors (Table 4). Location 11 was the only location with five limiting factors, the highest number of limiting factors out of all of the study locations. Soil samples featuring three limiting factors were dominant, accounting for 12 locations. Nine locations featured two limiting factors, 7 locations featured four limiting factors, and 4 locations only demonstrated one limiting factor. Given the soils investigated in each district were located in agricultural production centers, it could be suggested that the majority of agricultural land in Indonesia would be classified as suboptimal soil according to the scale adopted by this study.

Consequently, these results warn that soil conditions in the agricultural centers of many districts in West Java-and, in particular, those in the areas of poor soil quality-require attention, including restoration of SQ to enable farms to reach productivity targets. Unsatisfactory SQ at study sites can be understood as indicating that soils in these agricultural centers have been used intensively without appropriate or adequate soil management. Research by Martunis, et al. (2016) concerning SQ in the context of dryland agriculture in Aceh Besar similarly found SQ to vary between medium and good, while Arifin, et al. (2016) assessed SQ in the dryland agriculture context in Lombok, West Nusa Tenggara, Indonesia and found the majority of the soil to be of poor quality.

Given all of the research, locations were located in agriculture centers, the variation in soil properties might also indicate that the effect of different management systems, customs, agricultural schemes, and patterns of soil management, especially fertilization systems. The low levels of organic carbon content found at almost every research location indicated that most farmers had not used organic fertilizers properly. Intensive agriculture without the appropriate application of organic materials has thus caused organic carbon to deplete. It is also evident that most farmers in the research locations had not properly or adequately applied nitrogen and phosphate-based fertilizers.

\section{Conclusion}

The soil assessment system SQI-Plus accurately assessed soil quality in a dryland farming context using samples from five regencies in West Java, Indonesia. Eleven parameters were used to create a dataset: effective depth, texture class, bulk density, drainage, $\mathrm{pH}$, cation exchange capacity, total organic nitrogen, available phosphate, exchangeable potassium, aluminum saturation, and total organic carbon. The majority of the soils studied were classified as "medium" quality, with the most common limiting factors being low levels of organic carbon, available phosphate, and total organic nitrogen. Management of fertilizer application, especially organic fertilizers, phosphate- and nitrogen-based fertilizers, and agricultural lime should be implemented at locations observed to be in critical need of intervention.

\section{Acknowledgments}

The author gratefully acknowledges the Ministry of Research, Technology, and Higher Education of the Republic of Indonesia for their financial support in the form of a research grant from the Advanced Applied Research Scheme of Higher Education.

\section{Declaration of Competing Interest}

The authors declare no competing financial or personal interests that may appear and influence the work reported in this paper.

\section{References}

Arifin, Z., Susilowati, L. E., \& Kusuma, B. H. (2016). Perubahan indeks kualitas tanah di lahan kering akibat masukan pupuk anorganik- organik. Jurnal Agroteksos, 26(2), 1-17.

Bünemann, E. K., Bongiorno, G., Bai, Z., Creamer, R. E., De Deyn, G., de Goede, R., ... Brussaard, L. (2018). Soil quality-A critical review. Soil Biology and Biochemistry, 120(January),

105-125. https://doi.org/10.1016/j.soilbio.2018.01.030 
Doran, J. W., \& Parkin, T. B. (1994). Defining and assessing soil quality. In J. W. Doran, D. C. Coleman, D. F. Bezdicek, \& B. A. Stewart (Eds.), Defiining Soil Quality for $A$ Sustainable Environment (pp. 1-21). Madison: Soil Science Society of America and American Society of Agronomy. https://doi.org/10.2136/sssaspecpub35.frontmatter

Doran, J. W., Sarrantonio, M., \& Liebig, M. A. (1996). Soil health and sustainability. Advances in Agronomy, 56, 154. https://doi.org/10.1016/S0065-2113(08)60178-9

Harris, R. F., \& Bezdicek, D. F. (1994). Descriptive aspects of soil quality/health. In J. W. Doran, D. C. Coleman, D. F. Bezdicek, \& G. B. Stewart (Eds.), Defining Soil Quality for A Sustainable Environment, SSSA Special Publication 35 (pp. 23-35). Soil Science Society of America and American Society of Agronomy. https://doi.org/10.2136/sssaspecpub35.c2

Imaz, M. J., Virto, I., Bescansa, P., Enrique, A., FernandezUgalde, O., \& Karlen, D. L. (2010). Soil quality indicator response to tillage and residue management on semiarid Mediterranean cropland. Soil and Tillage Research, 107(1), 17-25. https://doi.org/10.1016/j.still.2010.02.003

Karlen, D. L., Andrews, S. S., Weinhold, B. J., \& Doran, J. W. (2003). Soil quality: humankind's foundation for survival a research editorial by conservation professionals. Journal of Soil and Water Conservation, 58(4), 171-179.

Karlen, D. L., Gardner, J. C., \& Rosek, M. J. (1998). A soil quality framework for evaluating the impact of CRP. Journal of Production Agriculture, 11(1), 56-60. https://doi.org/10.2134/jpa1998.0056

Karlen, Douglas L., Hurley, E. G., Andrews, S. S., Cambardella, C. A., Meek, D. W., Duffy, M. D., \& Mallarino, A. P. (2006). Crop rotation effects on soil quality at three northern corn/soybean belt locations. Agronomy Journal, 98(3), 484-495. https://doi.org/10.2134/agronj2005.0098

Kiani, M., Hernandez-Ramirez, G., Quideau, S., Smith, E., Janzen, H., Larney, F. J., \& Puurveen, D. (2017). Quantifying sensitive soil quality indicators across contrasting long-term land management systems: Crop rotations and nutrient regimes. Agriculture, Ecosystems and Environment, 248, 123-135. https://doi.org/10.1016/j.agee.2017.07.018

Martunis, L., Sufardi, \& Muyassir. (2016). Analisis indeks kualitas tanah di lahan kering Kabupaten Aceh Besar Provinsi Aceh. Jurnal Budidaya Pertanian, 12(1), 34-40.

Pansu, M., \& Gautheyrou, J. (2006). Handbook of soil analysis: mineralogical, organic and inorganic methods. Berlin, Heidelberg: Springer.

Rachman, L. M. (2013). Esensi dan kebutuhan terhadap penetapan kualitas tanah. Lokakarya Nasional Dan Seminar Forum Komunikasi Perguruan Tinggi Pertanian Indonesia, 749-763. Bogor.

Rachman, L. M. (2019a). Karakteristik dan variabilitas sifatsifat fisik tanah dan evaluasi kualitas fisik tanah pada lahan suboptimal. In S. Herlinda, B. Lakitan, W. Budiharto, I. Effendi, D. Adriani, M. Wijayanti, ... Tanbiyaskur (Eds.), Prosiding Seminar Nasional Lahan Suboptimal 2019, Palembang 4 - 5 September 2019 (pp. 132-139). Palembang: UNSRI Press.

Rachman, L. M. (2019b). Urgensi indeks kualitas tanah plus sebagai instrumen untuk penilaian dan monitoring kualitas tanah. Jakarta (Unpublished).

Sione, S. M. J., Wilson, M. G., Lado, M., \& González, A. P. (2017). Evaluation of soil degradation produced by rice crop systems in a Vertisol, using a soil quality index. Catena, 150, 79-86. https://doi.org/10.1016/j.catena.2016.11.011

Sparks, D. L., Page, A. L., Helmke, P. A., \& Loeppert, R. H. (2020). Methods of soil analysis, Part 3: Chemical methods. Medison, Wisconsin: Soil Science Society of America and American Society of Agronomy.

Tan, K. H. (2005). Soil sampling, preparation, and analysis (2nd ed.). Florida: CRC Press Taylor \& Francis Group.

Tesfahunegn, G. B. (2014). Soil quality assessment strategies for evaluating soil degradation in Northern Ethiopia. Applied and Environmental Soil Science, 646502, 14 p. https://doi.org/10.1155/2014/646502

Zuber, S. M., Behnke, G. D., Nafziger, E. D., \& Villamil, M. B. (2017). Multivariate assessment of soil quality indicators for crop rotation and tillage in Illinois. Soil and Tillage Research, 174, 147-155. https://doi.org/10.1016/j.still.2017.07.007 


\section{Appendix}

Appendix 1.The results of the laboratory analysis of parameters used as a database for scoring

\begin{tabular}{|c|c|c|c|c|c|c|c|c|c|c|c|}
\hline \multirow{2}{*}{$\begin{array}{l}\text { Location } \\
\text { Number }\end{array}$} & \multicolumn{11}{|c|}{ Soil Parameters } \\
\hline & 1 & 2 & 3 & 4 & 5 & 6 & 7 & 8 & 9 & 10 & 11 \\
\hline Symbol & $\mathbf{S}$ & B & $\mathbf{T}$ & D & pH & cec & $\mathbf{N}$ & $\mathbf{P}$ & Po & $\mathrm{Al}$ & Oc \\
\hline Unit & cm & $\mathrm{g} \mathrm{cm}^{-3}$ & TC & & & me $100 \mathrm{~g}^{-1}$ & $\%$ & ppm & me $100 \mathrm{~g}^{-1}$ & $\%$ & $\%$ \\
\hline \multicolumn{12}{|l|}{ Corn } \\
\hline 1 & 30 & 0.79 & $\mathrm{HC}$ & $\mathrm{G}$ & 5.42 & 90.68 & 0.37 & 15.33 & 0.56 & 0.00 & 2.62 \\
\hline 2 & 59 & 0.95 & $\mathrm{SiC}$ & G & 4.30 & 63.81 & 0.31 & 4.19 & 0.22 & 0.36 & 1.59 \\
\hline 3 & 84 & 1.01 & $\mathrm{HC}$ & G & 4.82 & 18.55 & 0.24 & 12.64 & 0.56 & 23.26 & 1.50 \\
\hline 4 & 90 & 1.02 & $\mathrm{HC}$ & G & 4.96 & 21.05 & 0.23 & 5.29 & 1.06 & 1.63 & 1.95 \\
\hline 5 & 92 & 0.99 & $\mathrm{HC}$ & $\mathrm{F}$ & 5.70 & 23.27 & 0.14 & 2.58 & 0.90 & 0.00 & 1.86 \\
\hline 6 & 96 & 0.98 & $C$ & SG & 5.45 & 21.51 & 0.35 & 21.34 & 0.89 & 1.07 & 1.98 \\
\hline 7 & 94 & 0.89 & C & SG & 5.42 & 27.32 & 0.32 & 9.09 & 0.74 & 0.84 & 2.45 \\
\hline 8 & 97 & 0.95 & C & SG & 5.62 & 27.76 & 0.25 & 48.79 & 1.58 & 0.00 & 3.16 \\
\hline 9 & 103 & 0.97 & $C$ & $\mathrm{G}$ & 4.79 & 22.43 & 0.14 & 3.60 & 0.73 & 0.76 & 1.10 \\
\hline 10 & 105 & 1.15 & $C$ & G & 5.48 & 19.91 & 0.16 & 26.06 & 0.55 & 0.00 & 1.65 \\
\hline 11 & 101 & 0.99 & $\mathrm{CL}$ & G & 4.94 & 21.85 & 0.15 & 3.70 & 0.24 & 0.95 & 1.48 \\
\hline 12 & 107 & 0.96 & $\mathrm{CL}$ & G & 5.60 & 18.31 & 0.09 & 3.97 & 1.39 & 0.00 & 1.17 \\
\hline \multicolumn{12}{|l|}{ Soybean } \\
\hline 13 & 105 & 1.06 & $C$ & SG & 5.95 & 17.63 & 0.15 & 3.43 & 0.56 & 0.00 & 1.64 \\
\hline 14 & 101 & 0.91 & $C$ & $\mathrm{G}$ & 5.52 & 24.76 & 0.14 & 3.36 & 0.60 & 1.66 & 1.73 \\
\hline 15 & 104 & 1.07 & $C$ & SG & 6.30 & 23.42 & 0.18 & 3.24 & 0.61 & 0.00 & 1.91 \\
\hline 16 & 104 & 0.99 & $\mathrm{HC}$ & SG & 4.34 & 22.61 & 0.19 & 3.01 & 0.63 & 19.28 & 1.67 \\
\hline 17 & 94 & 1.09 & $\mathrm{HC}$ & SG & 5.96 & 2.77 & 0.22 & 2.79 & 0.61 & 0.00 & 1.85 \\
\hline 18 & 95 & 0.94 & $\mathrm{HC}$ & SG & 5.67 & 27.74 & 0.20 & 12.20 & 0.55 & 0.00 & 1.63 \\
\hline 19 & 99 & 1.16 & $C$ & SG & 5.38 & 19.76 & 0.22 & 2.92 & 0.29 & 3.19 & 2.28 \\
\hline 20 & 91 & 0.90 & C & SG & 5.42 & 13.91 & 0.30 & 13.82 & 0.49 & 3.45 & 3.78 \\
\hline 21 & 102 & 1.11 & $S L$ & G & 5.05 & 16.52 & 0.28 & 106.24 & 0.74 & 0.51 & 0.95 \\
\hline 22 & 102 & 1.07 & C & SG & 6.01 & 35.87 & 0.33 & 3.21 & 0.79 & 0.00 & 1.44 \\
\hline 23 & 104 & 0.94 & $\mathrm{CL}$ & G & 5.62 & 23.80 & 0.16 & 104.57 & 1.49 & 0.00 & 1.41 \\
\hline 24 & 104 & 1.15 & $\mathrm{CL}$ & G & 5.34 & 21.49 & 0.16 & 27.82 & 1.17 & 0.11 & 1.17 \\
\hline \multicolumn{12}{|l|}{ Peanut } \\
\hline 25 & 102 & 1.29 & $C$ & $F$ & 5.95 & 24.05 & 0.12 & 3.04 & 0.66 & 0.00 & 1.47 \\
\hline 26 & 102 & 0.98 & C & G & 5.42 & 27.15 & 0.17 & 2.55 & 0.77 & 0.37 & 1.53 \\
\hline 27 & 107 & 1.16 & C & SG & 6.03 & 29.06 & 0.14 & 8.95 & 0.56 & 0.00 & 1.11 \\
\hline 28 & 103 & 0.95 & $\mathrm{CL}$ & G & 5.94 & 18.78 & 0.14 & 2.21 & 0.44 & 0.00 & 1.40 \\
\hline 29 & 90 & 1.09 & $\mathrm{HC}$ & G & 5.85 & 25.36 & 0.21 & 2.21 & 1.15 & 0.00 & 1.69 \\
\hline 30 & 92 & 0.94 & $C$ & G & 5.58 & 18.03 & 0.17 & 2.23 & 0.72 & 0.61 & 1.53 \\
\hline 31 & 93 & 1.16 & $\mathrm{HC}$ & SG & 4.84 & 13.96 & 0.22 & 2.46 & 0.45 & 0.00 & 1.60 \\
\hline 32 & 95 & 0.90 & C & SG & 5.65 & 19.70 & 0.27 & 9.13 & 0.50 & 0.61 & 3.20 \\
\hline 33 & 108 & 0.99 & $C$ & G & 5.05 & 16.52 & 0.43 & 3.67 & 0.49 & 0.00 & 1.14 \\
\hline 34 & 82 & 1.17 & SiL & G & 6.01 & 35.87 & 0.10 & 37.14 & 0.42 & 3.92 & 0.94 \\
\hline 35 & 89 & 1.22 & $\mathrm{SiC}$ & SG & 5.62 & 23.80 & 0.28 & 2.94 & 0.22 & 8.75 & 1.49 \\
\hline 36 & 89 & 1.23 & $\mathrm{HC}$ & $\mathrm{G}$ & 5.34 & 21.49 & 0.24 & 3.36 & 0.29 & 0.30 & 1.51 \\
\hline
\end{tabular}

Remarks: $\mathrm{TC}$ = texture class; $\mathrm{C}$ = clay; $\mathrm{HC}=$ heavy clay; $\mathrm{L}=$ loam; $\mathrm{CL}$ = clay loam; $\mathrm{SL}=$ sandy loam; $\mathrm{SiL}=$ silty loam; $\mathrm{SCL}=$ sandy clay loam; $\mathrm{SiC}=$ silty clay; $\mathrm{SiCL}=$ silty clay loam; $\mathrm{G}=$ good; $\mathrm{SG}=$ slightly good; $\mathrm{M}=$ medium; $\mathrm{S}=$ effective depth; $\mathrm{B}=$ bulk density; $\mathrm{T}=$ texture; $\mathrm{D}=$ drainage; $\mathrm{pH}=$ soil $\mathrm{pH} ; \mathrm{CEC}=$ cation exchange capacity; $\mathrm{N}=$ total organic nitrogen; $\mathrm{P}=$ available phosphate; $\mathrm{Po}=$ exchangeable potassium; $\mathrm{Al}=$ aluminum saturation; $\mathrm{OC}=$ organic carbon 